syndrome, was observed in the mother alone. Only one member (II.3) had obvious facial dysmorphism which is compatible with, but not specific for, the cri du chat syndrome. In at least three reports ${ }^{6-8}$ attempts were made to locate the 'critical' region in the cri du chat syndrome. They are compared in fig 3 with the deletion of band $5 \mathrm{p} 14$ observed in our family. The authors of these reports analysed over 40 cases with acceptable features of cri du chat syndrome, and located the phenotypically relevant site as distal to the deletion we report, although there could be a marginal overlap with our case. This may explain the minimal features of cri du chat syndrome noted in our family. However, the lack of consistency in the clinical features observed remains unexplained.

\footnotetext{
References

1 Baccichetti C. Del (5p) without "cri du chat" phenotype. Hum Genet 1982;60:389.
}

${ }^{2}$ Lejeune J, Lafourcade J, Berger R, et al. Trois cas de deletion partielle du bras court d'un chromosome 5. C R Acad Sci [D] (Paris) 1963;257:3098-102.

${ }^{3}$ Niebuhr E. The cri du chat syndrome. Epidemiology, cytogenetics and clinical features. Hum Genet 1978;44:227-75.

${ }^{4}$ Gordon RR, Cooke P. Facial appearance in cri du chat syndrome. Dev Med Child Neurol 1968;10:69-76.

5 Breg WR, Steele MW, Miller OJ, Warburton D, de Capoa A. The cri du chat syndrome in adolescents and adults: clinical findings in 13 older patients with partial deletion of the short arm of chromosome No 5 (5p-). J Pediatr 1970;77:782-91.

${ }^{6}$ Garcia FP, Garrabou LB, Mezquita GA, Garcia VA, Garcia MLM. Chromosome deletion point in cri du chat syndrome. An Esp Pediatr 1976;9:170-3.

${ }^{7}$ Lewandowski RC, Yunis JJ. Phenotypic mapping in man. In: Yunis JJ, ed. New chromosomal syndromes. New York: Academic Press, 1977:369-94.

${ }^{8}$ Niebuhr E. Cytological observations in 35 individuals with a 5p- karyotype. Hum Genet 1978;42:143-56.

Correspondence and requests for reprints to Ms J L Walker, Centre for Human Genetics, 117 Manchester Road, Sheffield S10 5DN.

\title{
A live infant with trisomy 14 mosaicism and nuclear abnormalities of the neutrophils
}

\author{
B DALlaPicCOLA*, G FERRANTI*, A GiAnNOTTI†, G NOVELLI*, \\ L PASQUINI†, AND B PORFIRIO*
}

${ }^{*}$ Department of Human Genetics, University of Urbino; and †Bambin Gesù Hospital, Rome, Italy.

SUMmaRY Mosaic trisomy 14 is described in a patient with severe developmental retardation and congenital malformations. Together with a few previous reports, this case suggests the existence of a syndrome associated with this chromosome imbalance. Hitherto unrecognised manifestations of trisomy 14 mosaicism were, in our patient, abnormalities of the neutrophil nuclei, which consisted of multiple pedunculated or sessile projections, similar to those characteristically associated with trisomy 13 syndrome.

Trisomy 14 accounts for less than $1 \%$ of chromosomal aberrations observed in spontaneous abortions. ${ }^{1}$ The lethality of this aneuploidy is attested by its almost complete absence among liveborn infants and by the observation that trisomy 14 mosaicism was invariably present in the few living subjects with this imbalance. ${ }^{2-7}$

Received for publication 10 April 1984.

Accepted for publication 11 April 1984
We describe a new case of trisomy 14 mosaicism that supports the existence of a characteristic clinical condition associated with this aneuploidy and suggests that nuclear abnormalities of the neutrophils could be an additional feature of the syndrome.

\section{Case report}

The proband was born in 1983 after a 40 week pregnancy complicated by threatened abortion during the second month and by polyhydramnios. He was the only child of healthy, unrelated parents. At birth the mother was 33 years old and the father 32 . Birth weight was $2400 \mathrm{~g}$ ( $<3$ rd centile; 50th centile for 34 weeks) and length $48 \mathrm{~cm}$ (3rd to 10th centile). At 24 hours the patient had a seizure. During the first months he stayed in hospital because of feeding difficulties and delayed growth resulting from bilateral cleft lip and palate and a congenital heart defect (tetralogy of Fallot), which was operated on at 3 months of age.

He was seen by us at 6 months (fig 1). At that time his weight was $3800 \mathrm{~g}(<3 \mathrm{rd}$ centile; 50th centile for 3 weeks), length $52 \mathrm{~cm}(<3 \mathrm{rd}$ centile; 50 th centile 


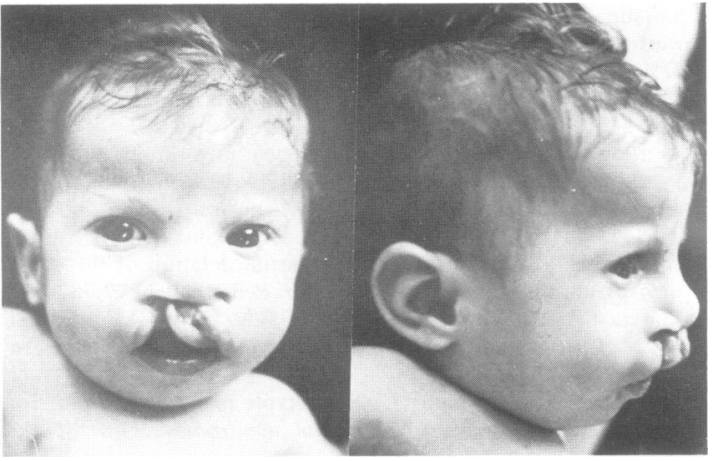

FIG 1 Proband at the age of 6 months.

for birth), and head circumference $38 \mathrm{~cm}(<3 \mathrm{rd}$ centile; 50th centile for 1 month). There was mild frontal bossing with a median haemangioma and a high anterior hairline. The glabella was normal and continued into a wide nasal bridge. The ocular region was characterised by hypertelorism, unilateral epicanthus, deep set eyes, upward slanting palpebral fissures, and sparse eyebrows. There was a wide bilateral cleft lip and palate and a bifid uvula . The chin was receding. The ears were low set and rather elongated in their horizontal axis. The root of the helix was prominent, the concha deep and long, and the tragus hypoplastic. The neck was short and there was pectus excavatum, hypoplastic external genitalia, and bilateral cryptorchidism. Dermatoglyphs on the hands were unremarkable, with eight loops and two whorls on the fingertips; total ridge count was not performed. The palms showed bilateral simian lines and proximally located axial triradii. Large dyschromatic patches extended over the lower limbs. The fifth toes were slightly hypoplastic. Neurological examination was basically normal. The electroencephalogram indicated dysfunction in the right temporal area. A CT scan of the head showed two hypodense areas in the right hemisphere. Skeletal $x$-rays demonstrated diffuse osteoporosis and a schisis of the first dorsal vertebral bodies.

Chemical and haematological laboratory data were normal. However, blood films showed abnormal granulocytes with a high frequency of sessile or pedunculated nuclear projections. About $40 \%$ of neutrophils had three to six of these appendages, their size ranging approximately from 0.25 to $1.5 \mu$ (fig 2). In addition, the individual nuclear lobes of the granulocytes were less distinctly separated.

The activities of erythrocyte nucleoside phos phorylase (E.C.2.4.2.1), glucose-6-phosphate de hydrogenase (E.C.1.1.1.49), adenylate kinase

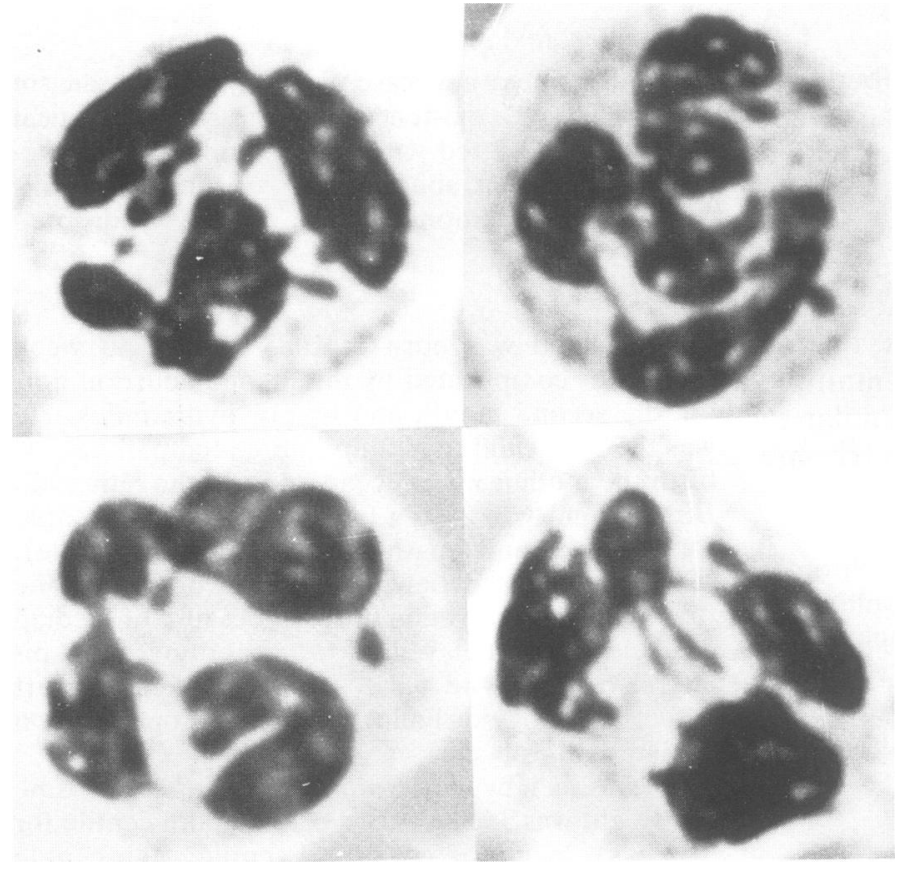

FIG 2 Appearance of nuclear projections in peripheral blood neutrophils from the patient. 
(E.C.2.7.4.3), lactate dehydrogenase (E.C.1. 1.1.27), adenosine deaminase (E.C.3.5.4.4), glutathione S-transferase (E.C.2.5.1.18), 6phosphogluconate dehydrogenase (E.C.1.1.1.43), guanylate kinase (E.C.2.7.4.8), and uridine diphosphate glucose pyrophosphorylase (E.C.2.7.7.9) were normal. The red blood cell content of adenosine nucleotides ATP, ADP, and AMP, as evaluated by an HPLC method, ${ }^{8}$ was in the normal range.

\section{CYTOGENETIC STUDIES}

Chromosome analyses were carried out on peripheral blood lymphocytes on two occasions. A total of 210 cells was examined. GAG banded metaphases showed a $46, X Y / 47, X Y,+14$ complement. The proportion of trisomic cells was $70 \%$. Satellite associations were investigated on 100 consecutive cells. It was found that the absolute frequency of association, after correction for the proportion of trisomic cells, was similar to that found in disomic controls. However, the absolute association frequency of chromosome 14 was higher and accounted for about half of the observed associations.

A total of 195 skin fibroblasts was analysed at the second passage. Only one cell showed a 47,XY,+14 karyotype, while the others were normal.
No chromosome abnormality was found in cultured lymphocytes of the parents.

\section{Discussion}

Six living patients with trisomy 14 mosaicism have been described previously. While the first case was identified only by means of autoradiographic analyses, ${ }^{2}$ all the others have been studied with banding techniques. ${ }^{3-7}$ Although the proportion of trisomic cells was different in individual cases, and the ages of the patients ranged between birth and 13 years, the overlap of clinical features allows the delineation of a distinct syndrome (table).

As expected in a postzygotic error, the parental ages were not significantly increased at birth. Pregnancy was at term in most cases and complicated by polyhydramnios in at least three. Mean weight at birth was $2872 \mathrm{~g}$ and mean length $45 \cdot 6 \mathrm{~cm}$. Microcephaly was recorded at birth in all patients (mean head circumference $33.8 \mathrm{~cm}$ ). The main clinical signs included frontal bossing, flat nasal bridge with a rounded nose tip, hypertelorism, horizontal or upward slanting palpebral fissures, epicanthus and, in two instances, the presence of an unusual translucent film over the eyes. The patients

TABLE Comparison of cases with trisomy 14 mosaicism.

\begin{tabular}{|c|c|c|c|c|c|c|c|}
\hline Findings & $\begin{array}{l}\text { Murken } \\
\text { et al }\end{array}$ & $\begin{array}{l}\text { Rethoré } \\
\text { et al }{ }^{3}\end{array}$ & $\begin{array}{l}\text { Martin } \\
\text { et } \text { al }^{4}\end{array}$ & $\begin{array}{l}\text { Johnson } \\
\text { et al }\end{array}$ & $\begin{array}{l}\text { Turleau } \\
\text { et al }\end{array}$ & $\begin{array}{l}\text { Jenkins } \\
\text { et al }\end{array}$ & $\begin{array}{l}\text { Present } \\
\text { case }\end{array}$ \\
\hline Maternal age & 37 & 32 & 26 & 16 & 26 & 30 & 33 \\
\hline Paternal age & 40 & 43 & 32 & 22 & 24 & $?$ & 32 \\
\hline Pregnancy (wk) & 40 & 43 & 42 & 40 & 34 & 40 & 40 \\
\hline Polyhydramnios & - & - & + & - & + & - & + \\
\hline Sex & $\mathrm{F}$ & $\mathbf{F}$ & $\mathrm{F}$ & $\mathbf{F}$ & $\mathbf{M}$ & $\mathbf{F}$ & $\mathbf{M}$ \\
\hline Birth weight (g) & 2850 & 3140 & 3260 & 2955 & 1900 & 3604 & 2400 \\
\hline Length $(\mathrm{cm})$ & 51 & 44 & 49 & 43 & 39 & ? & 48 \\
\hline Head circumference $(\mathrm{cm})$ & $?$ & 35 & 33 & $?$ & $32 \cdot 4$ & ? & 35 \\
\hline Age at examination & $30 \mathrm{mth}$ & $3 \mathrm{mth}$ & $1 \mathrm{mth}$ & $131 / 2 y$ & $7 d$ & $17 \mathrm{mth}$ & $6 \mathrm{mth}$ \\
\hline Evolution & $\begin{array}{l}\text { Living at } \\
30 \mathrm{mth}\end{array}$ & $\begin{array}{l}\text { Dead at } \\
3 \mathrm{mth}\end{array}$ & $\begin{array}{l}\text { Living at } \\
1 \mathrm{mth}\end{array}$ & $\begin{array}{c}\text { Living at } \\
14 \mathrm{y}\end{array}$ & $\begin{array}{l}\text { Dead at } \\
7 \mathrm{~d}\end{array}$ & $\begin{array}{l}\text { Living at } \\
17 \mathrm{mth}\end{array}$ & $\begin{array}{l}\text { Living at } \\
8 \mathrm{mth}\end{array}$ \\
\hline$\%+14$ in lymphocytes & 93 & 10 & 8 & 41 & 25 & 10 & 70 \\
\hline$\%+14$ in fibroblasts & $?$ & 10 & 3 & $?$ & $?$ & $1 / 164$ & $1 / 195$ \\
\hline Delayed growth & + & + & + & + & + & + & + \\
\hline Mental retardation & + & $?$ & + & + & $?$ & + & $?$ \\
\hline Prominent forehead & + & + & + & - & + & + & + \\
\hline Flat nasal bridge & + & + & + & + & + & + & + \\
\hline Palpebral fissures & Horizontal & Horizontal & Horizontal & $\begin{array}{l}\text { Downward } \\
\text { slanting }\end{array}$ & Narrow & $\begin{array}{l}\text { Hypoplastic } \\
\text { orbital rim }\end{array}$ & $\begin{array}{l}\text { Upward } \\
\text { slanting }\end{array}$ \\
\hline Hypertelorism & + & + & + & - & + & + & + \\
\hline Epicanthus & + & \pm & - & - & - & - & \pm \\
\hline Upper lip & Long & Long & Long & Long & Prominent & Long & $\overrightarrow{\mathrm{Cl}}$ eft \\
\hline Cleft palate & + & - & - & - & - & + & + \\
\hline Low set/malformed ears & + & + & + & + & + & + & + \\
\hline Microretrognathia & \pm & + & + & + & + & + & + \\
\hline Short neck & $\overline{+}$ & + & + & + & + & + & + \\
\hline $\begin{array}{l}\text { Narrow chest } \\
\text { (pectus excavatum) }\end{array}$ & + & + & $?$ & + & + & $?$ & + \\
\hline Heart defects & + & + & $+(?)$ & $+(\mathrm{TF})$ & + & - & $+(\mathrm{TF})$ \\
\hline Others & $\begin{array}{l}\text { Hypotonia, } \\
\text { skeletal } \\
\text { dysmorphism }\end{array}$ & $\begin{array}{l}\text { Hip dislocation, } \\
\text { prominent } \\
\text { heels }\end{array}$ & $\begin{array}{l}\text { Hypotonia, } \\
\text { clinodactyly } \\
\text { of } 5 \text { th fingers }\end{array}$ & $\begin{array}{l}\text { Skeletal } \\
\text { asymmetry, } \\
\text { chronic } \\
\text { dermatitis, } \\
\text { asthma }\end{array}$ & $\begin{array}{l}\text { Cryptorchidism, } \\
\text { renal failure, } \\
\text { hip dislocation }\end{array}$ & $\begin{array}{l}\text { Facial } \\
\text { asymmetry, } \\
\text { short } 5 \text { th fingers. } \\
\text { stenosis of } \\
\text { exterior auditory } \\
\text { canal }\end{array}$ & $\begin{array}{l}\text { Cryptorchidism, } \\
\text { simian lines, } \\
\text { nuclear } \\
\text { projections } \\
\text { in neutrophils }\end{array}$ \\
\hline
\end{tabular}


had a long and prominent upper lip and all displayed microretrognathia. Bilateral cleft lip and palate was present only in our proband, but a cleft palate was reported in two other cases. ${ }^{2} 7$ Additional features of the syndrome were low set and malformed ears, short neck, and narrow and dysmorphic chest. Congenital heart defects were found in five of the seven patients. Cryptorchidism and hypoplastic genitalia were observed in the two males. Although skeletal defects do not appear as a distinguishing feature, hip dislocations were present in two cases. Dermatoglyphs were examined in three subjects and considered unremarkable. Two patients died within 3 months of birth; the surviving ones investigated beyond the first year of life were severely mentally retarded.

In five patients the cytogenetic abnormality consisted of a clone with an extra chromosome 14 in 8 to $93 \%$ of blood lymphocytes. Turleau et a $t^{6}$ described a mosaic trisomy 14 resulting from a de novo formation of an isodicentric chromosome, and Jenkins et $\mathrm{al}^{7}$ found a mosaic isochromosome of the long arm of chromosome 14 in a $14 q 15 q$ heterozygote. In general, the proportion of trisomic cells was lower in fibroblasts than lymphocytes.

No single enzymatic abnormality was demonstrated by extensive red blood cell studies performed in two cases. Even the nucleoside phosphorylase activity did not show the expected gene dosage effect in our patient. This result could well be due to the presence of a mosaic trisomy.

Special comment is needed on the observation in the present case of consistent nuclear abnormalities in the neutrophils. The high frequency of appendages of variable size and shape, together with the tendency of the individual lobes to be poorly separated, make these granulocytes very similar to those originally described in trisomy 13 syndrome. ${ }^{9}$ Available data have pointed to a relationship between these nuclear projections and the extra set of satellites carried by the extra chromosome 13. In fact, an increased number of small clubs is not a feature in the neutrophils of patients with translocation trisomy 13. However, the same also holds true in subjects with extra $\mathrm{G}$ group chromosomes or with partial aneuploidy of D group chromosomes retaining the satellite regions. Huehns et al ${ }^{9}$ stated that nuclear abnormalities of the neutrophils are specific to trisomy D. Our patient with trisomy 14 mosaicism proves that this is not so. Rather, we think that it could also be a feature of the other, usually lethal, conditions associated with extra chromosomes 14 or 15.

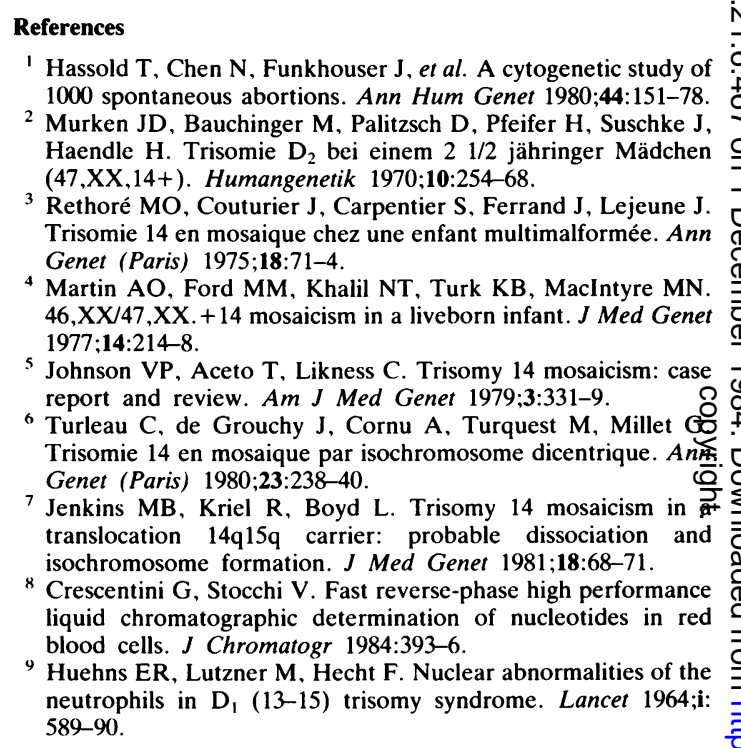

Correspondence and requests for reprints to Professor Bruno Dallapiccola, Cattedra di Genetica Umana, Università di Urbino, Via Saffi 2, 61029 Urbino, Italy.

\section{A rare heterochromatic variant of chromosome 4}

\section{ZOE DOCHERTY AND SUSAN M BOWSER-RILEY}

Department of Cytogenetics, Infant Development Unit, Birmingham Maternity Hospital, Queen Elizabeth Medical Centre, Edgbaston, Birmingham B15 2TG.

SUMMARY A variant chromosome 4 with a large $G$ positive heterochromatic block is described and discussed in relation to chromo-

Received for publication 16 March 1984. Accepted for publication 11 April 1984. some 4 heteromorphisms observed with other banding techniques. The extra heterochromatin is $\mathrm{C}$ positive and fluoresces brilliantly with $\mathrm{Q}$ banding, but differs from Yqh with some methods of staining. 